\title{
突験的エストロゲン過剩症に於ける病理組織学的研究
}

\section{Pathohistological Study on the Experimental Hyperestrogenism}

\author{
阿 部 俊 和* \\ Toshikazu ABE
}

\section{緒容}

所謂, 孚腺症や，子宮内膜境殖症，乳腺の線維腺腫，

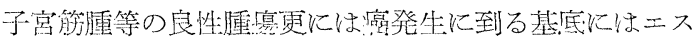
トログン過剩の存在がある事は, A. Lipschutz 1), Geschickter 2) 等に低つて確認され, Estrogen が Progesteron 之共河眮巣から分泌され微量で性器並びに性上位 部汇作用する结か，他の内分泌腺や，体内の諸代謝とも 密接な関係があり, 特汇 Estorogen 過剩による性ホル モン不均衡に大きな病因的意議の有る諸疾㭧が指摘され て居る.又，去勢動物て性ホルモンを投与した際の，諸

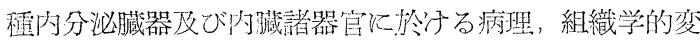
化汇関して，殊沉关の投与量，撖与期間濰じて起る諸 変化について，綜合的知見に尔けている点から，本実験 を試みた。

\section{実験方法}

实験動物：体重 2.0 2.5kg の成熟家禹 28 匹

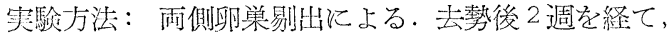

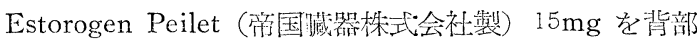
皮下に移殖桿を以て插入し，1回の插入に低り約 2 週閒 の持続的效果学利用して, 第 2 回を插入し，以後 2 週閌



I. Estrogen Pellet $(15 \mathrm{mg})$ 插入, 去勢家鬼群 第 1 群 4 匹（家躳番号 $2,7,19,30$ ）去勢後 2 週 1 回扥入, 2 週経過後尿殺

第 2 群 4 匹（家束番号 17，18，20，10）去勢後 2 週 每に 2 回插入 (全量 $30 \mathrm{mg}$ ), 2 週経過後屠殺

第 3 群 4 元（家雭番号 $15 ， 16 ， 4 ， 5$ ）去勢後 2 週每 に 3 回插入 (全量 $45 \mathrm{mg}$ ), 2 週経過後屠殺

第 4 群 2 匹（家鬼番号 11，12）去勢後 2 週年に 4 回 插入 (全量 $60 \mathrm{mg}$ ), 2 淍経過後屡殺

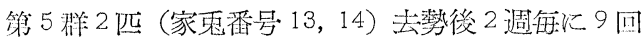
插入（全量 $135 \mathrm{mg}$ )，2週経過後屠殺 計 16 匹

II 刘照去攀家來群

去勢後 1 週経過後屠秘（家雨番号 1，3）去樊後 2 週経

* 順天堂大学医学部病理学教室 1961 年 1 月 13 日受付
過後屠殺（家禹番号 9 ）。去勢後 4 週経過後殺（家雨番 号 24, 28), 去勢後6 週経過後殺（家业番号 23, 25）, 去 蜉後 8 週， 10 週及び 20 週経過後殺（家种番号 26,27 及 び31) 計 10 四

III 対照正常家雨（家禹番号 $\mathrm{K}_{1} \mathrm{~K}_{2}$ ) 計 2 匹

笑験動物は多く空気栓塞を以て殺し，直ち涪検，全 身内分泌臟器, 子宮, 肝, 算, 瘏, 乳腺等を剔出しホル マリン固定，パラフイン切片又は凍結切片をつくり， H. E. アザンマルリー，PAS，鉄反忘，エラスチカ，脂肪 等の諸染色を行い, 必要あ机ば, カルノア液固定, 原染 色を試みて, 病理組織学的検査を行つた。



\section{3. 実験成 樍}

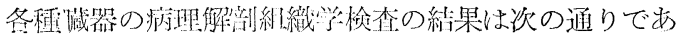
つt.

\section{A. 子宮}

去勢家雭に於ては正常成熟家雨と此較するに，子宫は

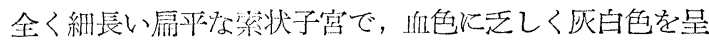
乙, 組織学的に内膜上皮細胞には增殖, 肥大はなく, 内




少く狭少となり，内膜固有買も菲薄で，小紡鍾形濃染核


て菲薄である。体部上皮は一般に娍子状で，核は小卵円 形濃染し，原形質は塭基好性で吕しく，空泡形成等は認 められない，即ち著明な去勢萎縮像が認められた。

去勢後 Estorogen Pellet 插入例では, 明かに内膜増 旗を示し，大量長期間 Estorogen Pellet 插入例では内


群では，内膜上皮細胞は丈高くなり高円柱状で，原形質 は淡明となり豊富である。又，核も膨大して大卵円形， 淡明となる.子宮腺も增生して稍々扰張して見兄る。

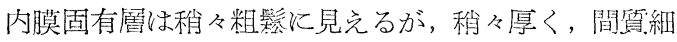
胞は核膨大乙淡明な卵円形核を有乙, 之等に僅乃泊血

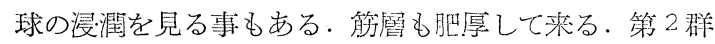
では内膜上皮細胞は第 1 群と同様の形態を示すが，懕々 多層性に上皮增殖を示儿, 核分剖像もかなり多く認めら れる、矢の一部は変性脱落して内腔中浮遊している。 子宮腺の增生もかなり著しく, 一部では小鼠胞性拡張を 示す．内膜固有副は粗鬆に見光，間質細胞も膨大して淡 明な大卵円形核を有し，白血球浸潤も稍々著明となる。 筋層も明かに增殖性肥厚を示して居る。倚, PAS 染色 では内膜上皮, 子宮腺上皮は明かに原形質が著明に PA $\mathrm{S}$ 陽性で内膜固有層の表層にもかなり多く，又，小動脈


多量に䞏められる。第了群では, 子宮腺は著名な垔性胞

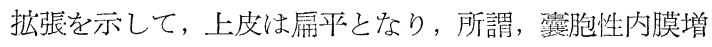
殖症の形態を示し, 又, 䚄々内腔に腺腫状万至ポリープ 状に増殖を示して居り，白血球漫潤が著しくなり，小動 脈壁はかなり肥厚して, 筋層は部分的滵ろ菱縮性とな り，血管周囲の結合織が増光て来る。第 4 群で浪队膜は 大部分が壊死性となり一部に石扊沈着を示す。第 4 群で は変性乃至類䏅死を示す。内膜上皮の邊残が認められ，

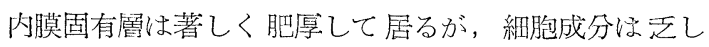
く, 毛細血管”, 静脈が, 高度に充血扰張を示し一部には フイブリン血栓が認められ，小動脈は著明な壁の肥厚 を示して居る、㙝層は著しい毛細血管の充血拡張を伴 い, 甚だしく萎縮性で, 間質結合織の堌成が目立つて居 る. 第 5 群では, 内膜は勿論, 外縦筋層迄が広沉懐死

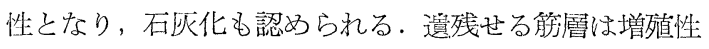
で一部は漿膜下に米粒大に結節状筋腫様增生を示して居 る・小動脈壁はかなり肥厚が目立つ.

B. 乳腺

去樊群に於ては, 去勢後期間の短い間は正常対照群之

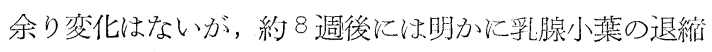

を認め, 乳管上皮は丈が低くなり，原形質に之しく，核 も小さく濃染し, 乳管は秒々小翼胞状法掁する。約 10 週では小葉は全く退縮して認められず，唯拡掁した大乳 管のみが膠元線維より成る粗硕な結合織中に散在して居 るに過ぎなくなる。然しながら，去勢後 Estorogen Pellet 插入群汇於ては, 第 1 群况孚管の 分岐崩苯が著明で 腺管の垻殖之共に管周图に線維芽細胞の多い好若な結合 織性增殖を示し, 所謂, 線維腺症とも云ら叮き像を示 す。增生する腺管の上皮は多賣性で, 上皮增殖症を示し て居り，核分剖像も賬々認められる。上皮細胞は文高く なり膨大して，原形質も豊富になり，又榕も膨大して，

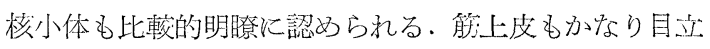
つて見光る。第 2 群快第 1 碓汇見られる乳管の增生か ら, 小葉間孚管から終末脬管分岐つよく, 買常孚、管腺增 殖が久られ，更に膨大せる小葉形成即ち乳細管の增生が 目立ち, 所謂 Acinar Adeuosis の像を示して居る. 第 3 群では小藻間乳管からの異党乳管腺增殖が 明睦とな り, 所謂, Acinar Adenosis が更に高度となる他に小 葉間乳!管, 終末乳!管の 执張が 認められ, 琈:細管も增生 し, 内腔にはェオジンで淡染する分泌液が貯溜して居 る. 第 4 群では增生せる小葉像は全く不明膫となり, 上 皮增殖を示す乳管の增生がある一方に, 垔胞性の拡張を 示す乳管が混在して居る。第 5 群では鼠胞性㹡胞を示す 乳管上皮は全く扇平となり，大囊胞形成を示して，その 濃縮した内容に石灰沈着が認められる。小葉構造以全く 認められず, 周国結合織の硝子化があり, 所謂, 大囊胞 性脬.腺症の像酒近い。

\section{C. 内分泌藏器}

(1) 脳下垂体

去勢群では下垂体は一般に刘照正常群と比䡥して大き く, 中, 後葉には特汇認它可き変化はない, 前葉に於て は, 組織学的に去勢後に, 毛細管の充血抎張が認められ たが，去勢後々期の例では余り著明でない，前集実質細 胞では，エオジン好性細胞は一般に淡染性で，核の不整 形なものが比輍的多く, 軽度に增加して居る。色素婎性 細胞は余り著明な変化はないが，塭基好性細胞は前葉実 質細胞中，去勢任低り比較的著名な变化を示して括り， その発現增加及び軽度の細胞肥大が認められる。即ち去

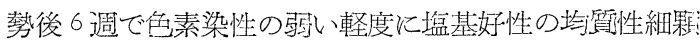
粒性の原形貿を有し，核のクロマチン絧の粗な盐基好性 細胞が軽度に增加して認められ，去勢後８週では，その 增加は更著しく，泡体内に等脃形成もかなり多く認る られる。然しながら Hohlraum-bildung を示す Siegel-




られない。

去勢後 20 週では核は色素様性細胞以似て大型で, 核 のクロマチン網が粗で，胞体は淡塩基好性或は amphophil の染色性を示す大型細胞が非常棌く認められる. この大型細胞は又, 去勢後 4 週よりその出現を認める. 即ちこの大型細胞は塩基好性細肘の消長と関連があり， Kraus ${ }^{3)}$ (1914) の云う移行型, Biggart 4) (1934〜35)

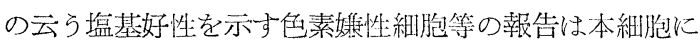
就ての示唆を与兄て居るものと考兄られる。

去勢後エストロゲンペレット挿入莋に址ては, 第 1 群

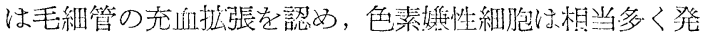
現して和り一般に核が大型で，关のクロマチン網も粗な ものが多い．エオジン好性細胞の発現尔かなり多いが， その核はかなり不整な者多く, 胞体は土オジン淡染性 で，その顆粒も微細で坛質性汇近い，程基好性細胞は少


体中に小架泡像を認める。符 2 群で性，毛細血管の抎㖘 充血㐫り，色素媒性細胞の発現は多いが核は大型で粗な クロマチン網を示村ものもある。エオジン好性細胞はか なり多く発現し，核は一般汇小形で，ヘマトキシリン 濃染坐で，核網は緻密なものが多いが，文不整な淡染性 の核を示するのもある.胞体は中等大でェオジン染性は 稍々弱く顆粒性は極めて微細なるのが多い，塩基好性細 胞は少く，核は稍々小核で，核網况微細なものが多く， 胞体子微細な顆粒性を示す。第３群では，毛細血管の拢

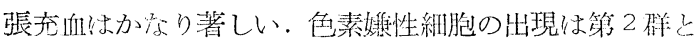
比して大差はない。ェオジン好性細胞はかなり著しく多 数出現增加を示して居り，核網の緻密なへマトキシリン 濃染を示す円形核を有し，胞体は中等大でエォジンに賑

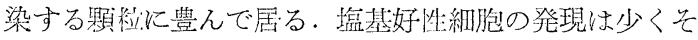
の咆体の顆粒性も不明䐲なものが多い，第 4 群でも毛細

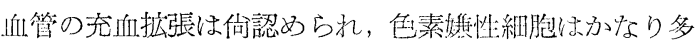
く発現し，核は大小程々で步るが，核網は一般に粗であ る。エオジン好性細胞は第 3 群に比して, 炎の発現は稍 々少く，核は一般に円形乃至卵円形で，核網は眯で暦々

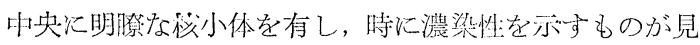
られる。胞体は大型でェオ゙ジン梁性の良好なものが多 い, 稀比大型核を有し，エオジン淡染性起示可胞体を有 するものも認められる。塩基好性細胞第 3 群と略々同 樣稙めて少なく，胞体の顆粘性:は不明膫である。第 5 碓

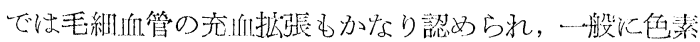
濑性組胞が著しく多く出現し，㮥大型で核絧も柾であ る、エオジン好性組胞の出現怯全く少く, 核小体の明か な棪絧の粗なけ形校を有与る定型的なものは全く娍少し
て，一般に暗調性の中等大の円形核を有し，エオジン淡 染性で, その顆粒の微細或いは坽貿性に近い胞体を有す る、部位によつては濃縮した秋を有するものもかなり多 く見られる.塩基好性細胞の発現は極めて少数で，胞休 の顆料性は不明䐲なものが多い。

\section{(2) 副篎}


洔鄞かに增量するが，去勢後長時日を経ると従つて著明 な縮少を来す。組織学的には Sudan III 像炕就ては Lipoid の配分飞著差はないが，去勢後 4 週以上に於て束 状層上部に脂媩が減少し，へマトキシリン，エオジン染 色䅺本では去勢 2 週後には皮薄細胞は掌万肥大し静脈洞

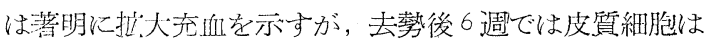

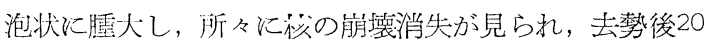
週では束状層に細胞の退行变化著明で，組織は甚しい荒 廃像を示して居る. 去勢後 Estrogen Pellet 插入群に 於ては, Estrogen の投与量の增加に伴つて明が副婜 皮質の增大が認められ，組織学的には第 1 㗏では明らか


の梁留から網状境にかけて軽度の細胞增殖を示して居 る. Sudan III 染色では束状層表痘に脂肪は佾少いが，


状異は正常であるが，束状層の細胞肥大增生著しく，特

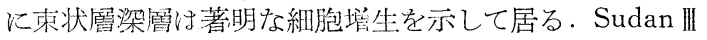

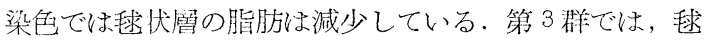

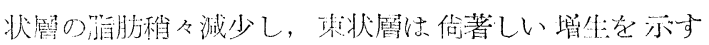
が，少数の細胞は退行变性を示して，核濃縮を示与者が

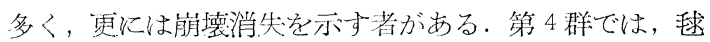

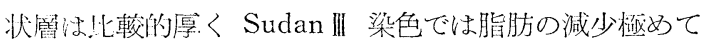
著しく, 束状層より網状層にかけて, 細胞は微細な脂肪 顆料で充たされて居り，H.E 染色では，核濃縮を示す 者が著しく多数に見られ，能塧消失走示与所が多い，第


かなり核濃縮を示す者が多く, 束状層小媴死巣が散在し て認められ, 核の濃縮, 崩塙消失が著明で, 皮質の荒廃 が著しい。

(3) 甲状腺

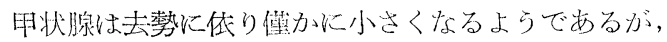
Estrogen Pellet 插入により叮かに略大を示して居る。 組織学的には去勢後 4 週以後では刘炤正嫦群に見ら机る



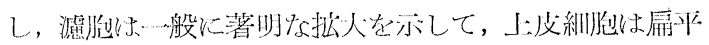
化して菱緥性であり,コロイドは著しく濃維して居る。 去勢後 Estrogen Pellet 插入砟に於ては, 筙1 1 群では 
去勢任依る甲状腺機能抑制像が消褪して正常対称群に見 られるものに近い，即ち，骰子状上皮より成る小濾胞が 多数出現して, 濾泡の著しい搥張は認められない。第2 群では, 濾胞は一般汇縮小して上皮は丈高く骰子状とな り, コロイドは淡く壁在空泡形成が著明認められ, 間 質毛細管の充血拨張を認める. 即ち, 明かに甲状腺の刺 皒墫殖像が認めら机る。第 3 群第 4 群では略々第 2 群と 著しい差はないが，濃愿なコロイドを容れる比較的大き な濾泡が偘かに出現して，問質の毛細管の充血拆張が明 らかである。

第 5 群では第 4 群匹見られた像之は全く異り，濾胞は 一般飞著しく掂大して上皮細胞は扇平となり濃染するコ ロイドの貯溜が著しい。

(4) 脺臟气の他の内分泌腺

膵臓ランゲルハンス上島及び唾液腺には特に著しい変 化を認める事法出染なかつた。胸腺, 上皮小体, 松果腺 は十分に検案する特が出来なからた。

\section{D. 肝 臟}

去勢後特汇著しい変化は認められないが, 去勢後長期 間を経る例に於ては小葉の軽度縮小，2稌細胞の減少を 見る。去勢後 Estrogen Pellet 插入群で忙2核細胞が 增加し, 中心静脈, 静脈洞の㹡張充血が見られ, 更に, 第 5 群の如き大量長期投与例飞於ては肝小葉中心部の肝 細胞の退行変性が著明で，胞体内江 Sudan III 染色で染 まらない空泡形成が認められ，其原形質全く泡状とな

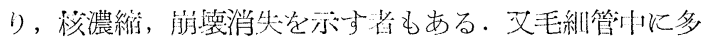
核白血球の增加が見られ，グリソン氏䩗にも白血球浸潤 之胆管の軽度の㧨張，小葉間胆管上りの軽度の小胆管分 岐增生を見る。增生せる小胆管上皮は細顆粒状の脂䏒顆 粒で充たされて居る，又，小葉周辺の肝細胞には著明な 血鉄素の沈着が見られる。

E. 脾 臟

去勢後特に著しい変化はないが，一般に静脈洞の扰張 充血著しい。

去勢後 Estrogen Pellet 插入群に於ては一般には静 脈洞の充血搥張と共に, Kurloff cell とも云われる P.

A. S 陽性顆粒で充たされた原形質を有する細胞及び担 鉄細胞が多数静脈涺中に認められる. 又, 長期注亘る大 量投与例では淋巴濾胞は一般に数少く，かなり縮小して 萎縮が認められる。

\section{F. 婜 缄}

去勢後 1 2 週では細㕄管主部上皮比見孔机る少化は 一様でなく, 或る部では上皮細胞の染色性減じ, 溷濁変 性を起し，又他の部では全く異常を認めない，一般に酤
部は曲部より変化が強い傾向が認められる。

去勢後4 週以上では細沓管主部上皮細胞の変性は著时 となり，备ネフロンが同様に変性湶つて居り，溷濁腫 脤著明となり, 胞体内汇可染性顆粒が多数現れ，場所飞 より Hyalin 小滴の出現を見る。又，一部には細胞基底 部に粗大な脂肪滴が出現して居る。

去勢後 Estrogen Pellet 插入群仿於ては, 第 1 群, 第 2 群, 第 3 群では主部上皮細胞の変性像は幾らか恢復 して居る様な印象を受沙るが，值部に於ては粗大顆䊀は 多数残つて居る。第 4 群及び第 5 群沉於ては主部上皮細 胞に著しい変性像が認められる。即ち, 細辰管主部上皮 細胞は稍々扁平となり, 管腔は挂張し, Hyalin 小滴, 大小の可染顆粒が多数認められ，細胞の基底部には所々 空泡様構造が多数現れて居る.一般に稼は円形濃染し, 稕濃縮の像を示し，臀々細胞の管腔側に位置して，原形 質突起の A pocrine 分泌と共に管腔中に稌の放出が見 られ，P.A.S 陽性の無構造物質即ち崩壊して剝離した細 胞形質と共飞管腔内に渚溜して認められる。細尿管遠位 部は一般に菱縮性に見光る。

\section{考按及び総括}

Lipschiitz 1) (1950) の "Steroid Hormons and Tu-

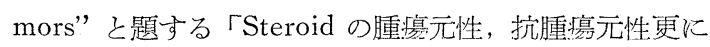
Steroid 均衡状態之抗腫瘍性自己防衛」に就ての著書に

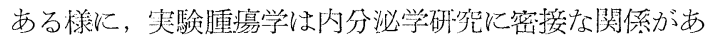

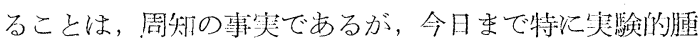


数多く見られ，就㚢性発情ホルモンであるエストロゲ ン投与に上る硼究は1930 年の始め頃より Lacassagne 等によりラッテ, マウス, 猿に就て基本的研“究が成され た。子宮に就てはその長期作用によりマウスやラッテに 于宮内膜の表皮化或いは時汇囊胞性增殖, ポリープ形成 更にはェンドメトリオーゼの起る事実が Lacassagne ${ }^{5)}$, Allen ${ }^{6)}$ 其の他多くの研究者に低り 報告されて居る. Lipschiitz はモルモットで, 子宮内膜腺上皮の化生と相 当に大きな腺腫様ポリープが少量の発情ホルモンによつ

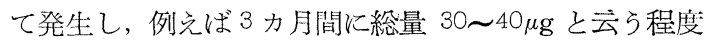
で充分であり，たざその作用が連続的でさえあればよい と云い，そ机には吸収の遅いェステル化 Estradiol, stilbesterol やとの Propionate の注射又は遊離型ホルモ ンペレットの皮下㨉入の方法によればよいと述べて居 る. Barahona7) (1949) はコレステロールを混じた 1\% のホルモンペレットによつても6週間でポリープを伴ら 覀胞状の腺增生を容易汇発生させた。 又, モルモットで は発情ホルモン投与により，75〜85日でェンドメトリ 
オーゼを起して居る事が Lipschiitz 等の实験で示され て居る、家來を用いた実験では Lacassagne が 1935 年

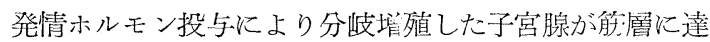
乙更にその中侵入する像を認めて扮り，此れをAdenofilromyoma と呼んだ. Pierson" ${ }^{8)}$ (1937), Hofbauer 9)（1940）もェストログン投与飞依り内膜埃殖症を家鬼 茩起せしめ, 墥殖した子宮腺が深く漿膜に迄つき破つ て居るのを認めて居る. 更に 1941 年に Horuing ${ }^{10)}$ は Estradiol-beuzoate のペレット皮下移植 7 ～8 月後に 家鬼子宮の線維符腫の発生を見たと報告して居る. 偷, Lipschiitz は nelson 等 $(1937$ 1939) がホルモンの長 期投与によりモルモットに発生したと報告した子宮類線 維 (Filroid) 腫汇就て詳てく検案した. 即ち 3〜4 カ月 間発情ホルモンを去勢モルモットに投与した結果, 子宮 角の背, 腹面, 子宮及び子宮傍組織内を始めとし, 其の 他腹腔内の到る所化大小種々の結節形成を認め，その組 織学的所見更㳊組織発生について述べて居る.

著者の実験では去勢後エストロゲンペレット 15〜30


週投与では明かな囊胞性增殖を示し, 腺腫様文はポリー プ状に内膜の腫韵性增殖を示して居るのが認められた。 此机等に於て筋層の肥大る認められるが, 䈈腫の発生は 見られず, 所謂, 類線維腫の発生も見られなかつた。 $60 \mathrm{mg} 8$ 週投与では内膜は類壊死义は壊死を示し, 内膜 固有層, 筋層の毛細血管, 静脈の著明な拨張充血があり 血栓形成も認めら机た. $135 \mathrm{mg} 18$ 週投与では内膜更に

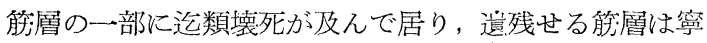
万增殖性汇見兄て，筋腫様結節性增殖を示寸所が見ら れ，子宮角の漿膜下に類線維腫の発生を認めた，何れの 症例に於ても所謂, エンドィトリオーセ様の変化は認め られず，此れには更に長期亘るホルモン投与が必要と 考兄られた。 又, 内膜の表皮化或いは化生は全く認㕫 れなからた. 乳腺流ては, Lacassagne ${ }^{11)}$ の研究以来 マウス・ラッテに依つて多数の報告が成されて居り, Gesebickter は投与量，投与方法の異る实験を多数のラ ッテ・マウスを使用し，乤の絬果種々の形の乳腺症類似 病変を起さしめ, 更には乳癭の発生を見た事を報告して 居る。教室の松本 ${ }^{12)}$ は犬に於て, 卵巣除去後エスト口 ゲンペレットを雨入产期间作川をさせる打比より管内乳

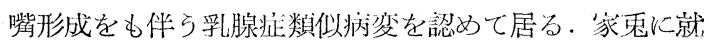
ての報告は知られて居ないので著者の研究に於て此の点 は興味があると思われる. 即ち, 去勢後エストログンペ レット $15 \mathrm{mg} 2$ 週間投与では去勢化依る菱縮像から, 明 かと乳管の分岐萠莱が著明となり，管腔は軽度に拡張

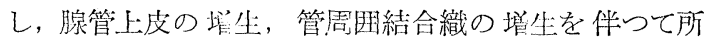
謂, 線維腺症様の病変を示して居り, $20 \mathrm{mg} \sim 45 \mathrm{mg}$ 4 6 週投与では小葉形成が見られ，冬小葉間乳管から異常 乳管腺境殖症も認められ, 小葉の膨大, 即ち乳紅管の埍 成が著しく認められる. 此秃は所謂, 腺房性腺症と云元 る. $60 \mathrm{mg} 8$ 週投与では小葉像は全く不明䐲となり, 腺

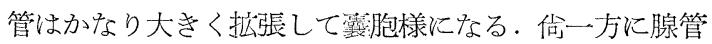
の異常の分岐增生像が遗残して所調 blunt duct adenoris が認められ， $135 \mathrm{mg} 18$ 週投与では囊胞性拡張を 示す大乳管上皮は全く扁平々なり，大䨋绹胞形成を示し， 内容飞一部石灰化を認め, 却つて小葉恃全く退縮して見 られず，周囲結合織は硝子化して所謂，大賈胞性孚腺症 の像江近い, 乳嘴腫, 線維腺腫形成更には発癭に及ぶ腫 澺形成は何れの例飞る認められなからた。

内分泌㵴器汇関しては，云勢依る性ホルモン欠㳊状 態の脳下垂体前葉に就いての 研究は Fichera 13) (1905) が初めて牛，マウス，秎等を使用して，下重:体の重量增 加, 奔血, 前葉酸好性細胞の增加と肥大が 報告され, Zachel 14) (1913), Schleidt 15) (1914), Addison 16) (19 16）は去勢ラッテ，マウスに於て塩基好性細胞の胞体 中に空泡を生じ，次第に空泡が大きくなり指輪型となる 事を報告し, 此れが去勢細胞として多くの研究者隹認め られて来た，そして，主势細胞は塩基好性細胞より由来 すると考光て居る研究者が多い，然しながら家雨化就て は去勢細胞当る变化は認めら机ないと云う者も居り， Kolde ${ }^{1 i)}$, Brauer ${ }^{18)}$ ( 酸好性細胞の增加を Smith and Seuering baus ${ }^{19)}$ は塩基好性絽胞の增加を，又 Kolde, Okints cbitz ${ }^{20)}$ は色素寒性細胞の增加を報告して居る が，横倉は色素媒性細胞の減少を報告して居る，著者の

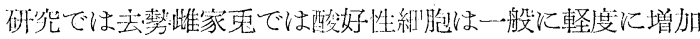
して居るが，エオジン淡染性の者が多く，塩基好性細胞 は去樊後6〜8週に於てとの增加が著明となり，胞体内 空泡形成もかなり多いが，指掄状の明かな法勢細胞と云

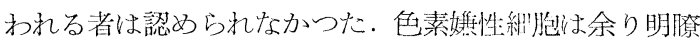
な差を認め難いが，去攀後20週では Kraus の云ら移行

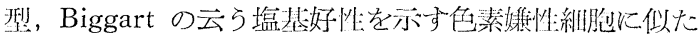
胞体淡塩基好性:或は Amphobil な大型細胞が 非常汇多 く認められた。

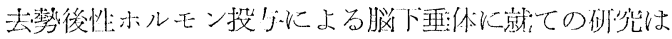
Fichera (1905), Schleidt (1914), Lehmann ${ }^{21)}$ (1927)

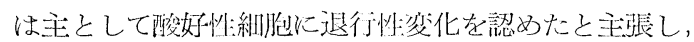
Zonder und Berlringer 22) (1931) 等 Fluhmann and Kulchar 23)（1931～32）は卵巣ホルモン投与飞より去勢

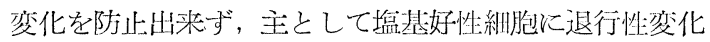


が認められたと述べておる．然しながら，Hoblweg 24) （1935）は卵巣ホルモン，男性ホルモンでは性特異性な く去勢変化に有効作用すると述べ，Lehmann は性特 異性は存するが，種特異性はなく去勢変化に有効に作用 すると述べ，偷一致した見解に欠ケて居る．酸好性細胞 に就ては Wolfe and Hamilton ${ }^{25)}$ (1937) 等は変化を 認めないと云つて居るが, 著者の成織では $15 \mathrm{mg} 〜 45 \mathrm{mg}$ 2〜6週投与では酸好性細胞はかなり多く，色素嫌性細 胞も多いが，塩基好性細胞は少い。 $60 \mathrm{mg} 8$ 週投与では 酸好性細胞の 発現は稍々少く, 色素媒性細胞かなり多 く, 塩基好性細胞は極めて少い. $135 \mathrm{mg} 18$ 週投与では 色素㥪性細胞が著しく多く発現し, 酸好性細胞は著しく 減少して, 退行性変性を示す者が多い, 塩基好性細胞は 全く少い。即わ，投与量と投与期間によつて著明な差異 が認められ，酸好性細胞は去勢後エストロゲン 15〜45 $\mathrm{mg}$ 2〜6週投与により次第に增加し，60 mg 8 週投与で 減少し, $135 \mathrm{mg} 18$ 週では著しく減少して Lehmann 等 の云ら退行性変化が著明となる.塩基好性細胞は細胞の 減少と共にとの塩基好性顆粒の減少が見られ Van Dyke 26) (1936), Wolfe (1937) 等の去勢変化の抑制が見られ た. 又, 色素嫌性細胞に就ては Wolfe and Wright 27) (1938), Dux :8)（1948）が色素倳性細胞の結節状堌殖を 認め, 多くの人は色素婎性細胞腺腫の発生を報告して居 る. 著者は，15〜 45mg 2〜6週投与では䅌々多く認め られたが，60mg 8 週投与ではかなり多く発現し，135 mg 18 週投与では著明に増加して居るのを認めたが, 腺 腫様增殖とは思われない。

副掔では女性ホルモンが欠乏すれば縮小し，女性ホル モンは刺㦸的に作用して居ると云われる. 即ら少くとも 畉巣機能低下は副婜機能の焦下を招来するが，卵巣の機 能が焦下する時は前葉の Gonadotropbin の增量があ り，此れは副婜皮質機能は此の為賦活される事になる。

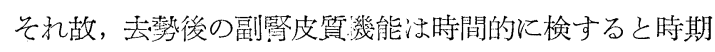
による差異を示すものと考えられる，著者の研究では土 勢後 2 週では皮質細胞は寧乃肥大し, 去攀後 4 週以上に 於て束状層表層の脂肪減少し, 去劸後6 週では皮質細胞 は泡状に肥大し, 核の崩㳖消失が見られ, 去勢後 20 週 では束状㞒の細胞の退行変性著しく認められた. Anderseu 29) (1934) は去樊䧳ラットに2 日間卵巣ホルモンを 与光副腎の肥大を認め, Korencheurky and Denmison 30) (1935) は大量エストロゲンを投与しても副緊肥大を 認めなかつた. Deanesly 31) (1939) は雄ラットでエス トロゲン投与の始めは副腎皮質は肥大し, 後には却つて 萎縮するのを認め, Hall 32)（1940）はエストラヂオール
を長期間（87〜105日）連用し, 網状層に充血と退行変 性を見た. 著者は 15〜45mg 2〜6週投与では球状層で は著明な変化は認められないが, 束状層は細胞は寧る肥 大し, 佮その表畨には佮脂肪は少いが, 去勢群と比べて は多くなり, 束状層梁層より網状層にかけては細胞増殖 が著しく見える. $60 \mathrm{mg} 8$ 週投与では球状層の貯蔵脂肪 の減少を示し, 束状層表層から網状層にかけて細胞は全 く脂肪顆粒で充たされて居り, 又樀濃縮崩壊を示し退行 変性が見られる。 又 $135 \mathrm{mg} 18$ 週投与では退行変性は 求状層にも及び, 束状尿には, 壊死巣が散在して見られ 皮質の荒廃が著しい。

甲状腺に就ては, Peusa ${ }^{33)}$ (1930), Krockert ${ }^{34)}$ (1934), 植田 35)（1954）が去勢に依り甲状腺は萎縮し, 機能が 倠下するが，エストロゲンを投与すれば組織学的にも機 能的にも旧に復すると述べて居る. Emge ${ }^{36)}$, SauchezCalvo ${ }^{37)}$ は卵巣ホルモンを少量短期間投与すると甲状 腺機能は一時的に元進するが, 大量長期間投与すると機 能を抑制する」と指摘した。

肝硬変に於活る甲状線の萎縮はェストロゲン過剰に低 ると云われ, 著者の実験に於てb去勢に依る退行変性像 はエストロゲン $15 \mathrm{mg} 21$ 週投与に依り消褪して, $45 \mathrm{mg}$ 6週投与では上皮骰子状となりコロイドの淡い小濾泡の 著しい増生を示して居り，60 mg 8 週投与では稍々大き な濾泡が少数出現して来て，135mg 18 週投与では上皮 㼛平となり濃槑なコロイドを充した大濾胞性となる。即 ๖ Emge. Sanchez-Calvo の指摘した事に全く適合する 所見が見られた。

其の他では膵臓ラ氏島には著変なく, 松果腺, 胸腺に 就ては十分に検案し得なかつた。

肝蔵に就ては土勢或いはエストロゲン投下に依る変化 の記戴は知られて居ないが, 肝臓はェストロゲンの不活 性化を営む事は既に明かであり，エストロゲン投与の実 験に於ても肝蔵に就ての検索は欠く可からざると考え

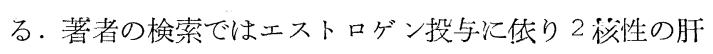
細胞が堌加し, 中心静脈, 静脈洞の充血掂張が見られ た. $135 \mathrm{mg} 18$ 週投与では肝小葉中必部の肝細胞の退行


失を示す者もあり，グ氏鞘に白血球浸潤が見られ，胆管 の軽度拡張, 小胆管, 分岐堌生が見られた。佮, 小葉周

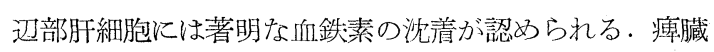
に於ては去勢に低つて特に著明な変化はないが, 静脈洞 の充血拡張が見られる。

エストロゲン投与では P.A.S 陽性顆粒.の豊富な所謂 Kurloff cell. 担鉄細胞が多数認められ, 細網内皮細胞 
の軽度增生を示し，長期に亘る大量投与では淋巴濾胞の 萎緶が認められた。

婜臓に就ては閉経期に高血圧になり易い事実りよ性ホ ルモンの腎臓に対する影響に関して関心が持たれ，その 形態学的研究は数少いが, Selye ${ }^{38)}$ (1939), Koreuchevsky ${ }^{39)}$ (1940) 等によつてェストロゲンに強い筱損傷 作用のある事が報告された。

著者の去勢による研究では，去樊後細尿管主部上皮に 軽度の退行変性が見られ，エストロゲン投与により去勢 に依る変性像が回復して見られるが，60〜135mg 8〜18 週投与では細尿管主部上皮細胞は稍々扁平となり管腔脑 張し, 硝子様小商, 大小の可染顆粒が多数認められ, 時 に空泡変性，秋濃染及び管腔中への稕の放出が見られ広

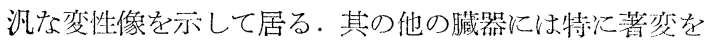
認める事が出来なかつた。

\section{結 論}

著者は，䧳成熟家鬼群を用い，去勢手術後一定期閒を 経て，エストルゼン・ペレット（15mg）を毎2週の間 隔を批いて，1，2，3，4，9回に亘つて，背部皮下に插入 して, 最終投与後 2 週を経て殺し, 投与全量 $15 \mathrm{mg}$ １35 mg. 投与期閒 2 週〜18 週によつて各々 4 2 匹の 5 群に 分ち, プロゼステロン効果を遮断して雭ら知験的過エス トルゼン症を起さしめ，一方备期の去勢効果を知るため に, 対照する各 2 匹の去勢家鬼 5 群と共に, 主として, 子宮, 乳腺, 下垂体, 甲状腺, 副婜, 腎, 肝等の病理解 剖組織学的検索を行つた。实験成績は投与エストルゼン 量並に投与期間を二大別出来た。即ち，

1. 去勢後 2 週後にエストルゼン・ペレット $15 \sim 45$ mg. 2〜6週投与例では, 去勢によつてよく萎縮菲薄化 した子宮内膜は著しい腺性檩殖を示し，菲薄化した筋層 も亦数倍汁肥厚する.去勢後 6 週までは非機能性の正常 対照例とあ屯り変らない乳腺は, 線維腺症, 腺房性腺症: 様に增殖し, 異常乳管腺買殖栄も出現する.去勢後 6 週 までは塩基泩子性細胞塯加のある下垂:休前葉に塩基性細胞

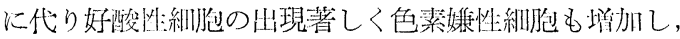
エストルゼンによつて去勢効果は抑制される。去勢後



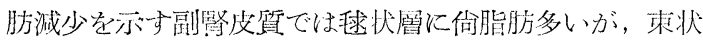

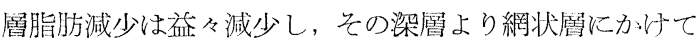
細胞肥大がある。甲状腺は去勢により機能低下し，コ口 イド濃縮，大滤胞となるが，エストルゼン投与によつて コロイド淡く，小濾胞化して機能昂進を示す．去樊後骎 期に至れば，菱縮の見られる肝蔵には，二核細胞增加
し，中心静脈静，脈洞充血按張する、去勢後荒変のない 脾にはエストルゼンの影響はない。去勢後 2〜4 週にし て著明となる警細尿管主部上皮の変性像はエストルゼン によつて回復する。

2. 去勢後エストルゼン・ペレツト $60 \mathrm{mg} \sim 135 \mathrm{mg}$ 8〜 18 週投与备群では，子宮内膜は白血球浸溜著しく，罜: 死，類壞死を示し，觗䍹内にまで波及して，子宮壁静

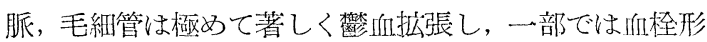
成を又る。但し镜残した筋層は寧ろ增殖性で $135 \mathrm{mg} 8$ 週群では獎膜下に類維々腫の形成を認めた。一時孚管の 分岐延長，上皮增生を示した乳腺は，小葉は全く退縮し て大囊胞性乳腺症の像を示し，周团基質がある，下更:体 前葉では好酸性細胞の減少珢化が見られ，塩基好性細胞 は著減し, 色素媒性細胞が之に代つて著盯に增加する。

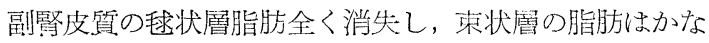
り多いが, 細胞輆の濃縮, 崩壞, 消失が見られ, $135 \mathrm{mg}$ 8 週群では正状層も退化し，束状贋には小壊死单散在 し，著しい荒廃を示す。一旦小濾胞化した甲状腺も再び 濃厚コロイドの貯溜に大濾胞性となる。長期大量投与群 に著しい，肝小葉中心部細胞に退行变性が見られ，グ上: 䩗に小胆管の軽度の前生があらわれる。脾臟は後期には 淋巴濾胞のつよい菱縮を見る。エストルゼンによつて一 旦恢復したと思われた婜細尿管主部の上皮は変性つよく なり, 㷉平化し, 管腔の拨張, 硝子様, 変性, 㿠濃染し 管腔内で核放出が見られ広汎にしてつよい変性像があ る。

擱筆するに臨み，御愁篤な御指導と御高閲を晹つ た伴教授並びに橋本教授に感謝し，殊に岡田孝男講 師のあつい御協力と教室員諸见に梁く㴬意を表しょ 于.

\section{文献}

1) A. Lipschutz: Steroid Hormones and Tumors (1950) The Williams and Wilkins Company. London.

2) C.F. Geschickter: Disease of the Breast. (1956) Philadelphia and London. Saunders Co. Zur Pathologg der Basophilen Zellen der Hypoluyse der Morbus Basedowi and Addisoni Virdrow

3) E.J. Kraus: Die Beziehungen der Zellen des Vor der lopplus der menschlichen Hypopluyse zueinader unter normalen Verbaltnissen und in Jumoren Zieglers Beitr. Path. Anat. allg. Patho$\log .58,1914$. 
4) Biggart. J.H.: The Hypopluysis of the luman castrate. Bull. Jolm Hopkins Hosp. 54, 1934. some obseruations on the basophile cells of the human hypophysis Edinhurgh med. J. 94, 1935. (E. Alleus Sex and Internal Secretion より引用)

5) Lacassagne. A.: Modifications progressives de l'ute'rus de la souris sous l'action prolongee' de l'oestrone. C.R. Soc. Ciolog. 120: 1156, 1935.

6) Allen. E: Estrogenic Hormon in the Genesis of tumors and Cancer Endocrinolog. 30, 1940.

7) Barahona. $\mathrm{M}$ : Aspectos cuantitativos del control de la función gonadotrófica de la hipófisis por el estrógeno.y su importancia para la patologia. Tesis Unsv. de Chile 1949 (Public Dep. Med. Exp. No. 70).

8) Pierson. H.: The infeuence of various hormones on tumor development in the uterus of the rabbit. Acta Unit Int. Cancen. 5, 1940.

9) Hoffbaner. J: Hormonal gynaecological pathology and its Chininal aspects J. obst. Gynec. Brit. Emp. 46, 1939.

10) Horping. E.S: Lipschütz "Steroid Hormones and Tumors”ょり引用.

11) Lacassagne. A: Apparition de cancers de la mamelle chez la sowris Mâle. soumise á des injections de folliculine C.R.Ac. Sci 195, 1932.

12) 松本和夫：日本病理学会雑誌, 48 巻, 総会号, 1959.

13) Fichira. G: Sur l'byplrtrophi de la glande pituitaire cousécuiive á la castration. Arch. ital. de Biolog. 43, 1905.

14) Zachel: In Biedl's Innere Sekration. 2 Aufl. II. urban and Schwarzenberg. Berlin-Wien 1913.

15) Schleidt. J : Über die hypoplupe bei feminierten Männchen und maskulierten Weibchen. zbl. physiolog. 27, 1914.

16) Addison. W.H.M: Cell changes in the hypoplupis of the Albino rat. after Gonadectomy Anat. Rec. 10, 1916.

17) Holde. W: Untersuc4mgen uon Hypophysen Bei schwangersc4aft und nach Hastration. Arch. Gynäkolog. 98, 1912.

18) Brauer. M: Experimentelle Untersuclumgen über die Einwirkung der Hastration auf neben- nieren und Hypoplupe beim Haninchen. Z. mikr.anat. Forsch. 16, 1929.

19) Smith. P.E and A.E. Severinghaus and L. Leonard: The effect of castration upon sex stimulating potency and the structwe of the anterior pituitary in rabbrts Anat. Ree. 57, 1933.

20) Okintschitz. L: Über die gegenseitigen Bezie hnngen einiger Prüseu mit innere Sekretion Arch. Gynäk. 102, 1914.

21) Lehmann. J : Über das staukturbild der Hypoplape Restrierter und nicht Rastruierter Ratteu unter dem Einfluss parenteral und enteral zugeführter Placeutarsubstauzen. Virchow. Arch 268 1928.

22) Zondek. B \& W. Berblinger: Der Einfluss des Weiblichen Sexualhormons und Hypopluysenvorder lappenhomone auf die Struktur der Mäuse und Ratteu hypophyse. Hlini. Wscer. 1, 1931.

23) Fluhmann. C.F and Hulchar. G. V: Castration cells in anterior hypophysis of spayed rat following prolonged administration of estrin Proc Soc. exp. Biol: Med. 28, 1930 1931.

24) Hohlweg. W: Corpus Luteum Hormon und kastrationshypophys. Klin. Wschr. 14, 1935.

25) Wolfe. J.M and J. B. Hamilton: Comparatine action of teststerone conpounds. of estrone and of combinations of testosterone compounds and estrone on the auterior hypophysis Endocrinol. 21, 1937.

26) Van Dykey: Physiology and Pharmacology of the pituitary body. Uniu. Chicago Press 1936.

27) Wolfe. J.M and A.W. Wright: Histologic effects induced in toe anterior pituitary of the rat by prolonged injection of estrin With particular reference to the production of pituitary adenomata. Endocrinol. 23, 1938.

28) Dux. C: Recherches microscopiques sur les adenomes hypophysaires du rat. Bull. du Cancer 35, 1948.

29) Andersen D.H J. Physiol. 83, 1934.

30) Koreuchewsky. V.u M. Deninson J. Path 41 : 1935.

31) Deanesly. R: J. Endorinol 1, 1939. 
32) Hall: Mölleudorf. W. u. W. Bargmann "Handbuch d. mikroskop Anat d. menschar より引用.

33) Peusa. P.G. Adoriau: Ber ü gesamt. gymär 18, 1930.

34) Hrockert G.: Ber ü. gesamt. Physiol. 76, 1934.

35) 植田安雄: 口産婦誌.

36) Emge. L.A.G.L. Laqueur. Endocrinol. 29, 1941.

37) Sanchez-Caluo: Zalu. H. "Schilddrüsen-Sexualhoamon” Klin. Wschr 16, 1937 より引用.

38) Selye. H: J. Urol. 42. 1939. J. Urol. 46, 1941.

39) Porenchevsky. V and M.A. Ross: Brit. Med. J. $1,1940$.

\section{附図説明}

图 1 子宮

(1) 正常対称群子宮 H.E $40 \times$

（2）去勢子宮 H.E $40 x$

（3）去勢後「I」投与第 I 群 H.E $40 \times$

子宮腺の増生が著明である。

（4）去勢後「I」投与第 2 群 H.E $16 \times$ 子宮腺の増生と小霊胞性拡張及び内膜, 基質の 肥厚が認められる。

（5）去勢後「I」投与第 2 群 カルノア固定, PAS 染色

内膜上皮は丈高くなり, 重層性上皮增殖を示 し, 胞体は PAS 陽性物質を充して居り, 内膜 基質表層にも多量の PAS 陽性物質が認めら れ, 小動脈壁, 肥大せる筋層の筋細胞中にも著 しく多い.

（6）去勢後 $「 I 」$ 投与第 3 群 H.E $16 \times$ 著明な囊胞性内膜增殖症を示して居る。

（7）去勢後「I」投与第 3 群 H.E $80 \times$ 内膜の子宮腔内に向う腺腫様增殖と, その上少 にポリープ状增殖.

（8）去勢後「I」投与第 3 群 H.E $40 \times$ 内膜ポリープの形成.

（9）去勢後「I」投与第 4 群 内膜類壊死性となり, 上部は内膜壞死の石灰化 せるもの。

（10）去勢後「I」投与第 4 群 Azan Mallory 40× 内膜基犋，筋層の毛細管，静脈の充沿挔張.

（11）去勢後「I」投与第 4 群 H.E $40 \times$ (10) と同じ.

（12）去勢後「I」投与第 5 群 H.E $40 \times$ 内膜は勿論, 筋周に迄及び広沉な壊死.
（13）去勢後「I」投与第 5 群 Azan Mallory $40 \times$ 子宮角に於ける漿膜下類線維腫の形成.

（14）去勢後「I」投与第 5 群 Azan Mallory $40 \times$ 外筋層に於ける小結節状筋腫様增殖を示す。

图 2 乳腺

(1) 正常対称洋乳腺 H.E $40 \times$

（2）去勢群乳腺 H.E 40 火 小葉消失し，腺管上皮は扁平となり，乳管の抾 張が著しい。

（3）去勢後「I」投与第 1 祉 H.E 40火 乳管の分岐增生著明で, 線維腺（腫）症に類似 せる所見を示す。

（4）去勢後「I」投与第 2 群 H.E 40 人 小葉形成を示し，細乳管の軽度增生あり，管腔 の拡張が著明である。

（5）去勢後「I」投与第 3 群 H.E 40 人 腺房性腺症が高度である。

（6）去勢後「I」投与第 4 群 H.E 40 人 小葉の退縮々管腔の霊胞様拡張が著明である。

（7）去勢後「I」投与第 5 群 H.E 40 人 Mastopatbia macrocystica に近い病变を示す。

図 3 脳下垂体

（1）去勢後 8 週 Azan mallory 400 火 塩基好性細胞の增加と, その胞体に出現せる小 空泡が見える。

（2）去勢後 20 週 Azan mallory 400火 核は色素憱性細胞に似て大きく, 胞体は amphophil 乃至僅かに塩基好性に見える大型細胞 の著しい出現.

（3）去勢後「I」投与第 1 群 H.E $400 \times$ 核の不整な淡染性酸好性細胞が多い。

（4）去勢後「I」投与第2 群 H.E $400 \times$ 濃染性酸好性細胞も多くなる。

（5）去勢後「I」投与第 3 群 Azan mallory $400 \times$ 浱染性酸好性細胞が著しく多くなる。毛細血管 の充血が見られる。

（6）去勢後「I」投与第 4 群 H.E 400 火 酸好性細胞減少して，色素茬性紐胞がかなり多 い.

（7）去勢後「I」投与第 5 碓 H.E 400 火 酸好性紐胞は全く少くなり，その然泡变性も見 られ色菜虾性細胞が著しく多くなる。

図4副腎

（1）去勢後 8 週 $80 \times$ PAS 
皮質細胞の泡状膨大を示し，所々に核の崩壊消 失を見る。

（2）去勢後 20 週 $80 \times$ Sudan III 束状層表層に脂肪が著しく減少する。

（3）去势後 $\Gamma I 」$ 投与第 1 群 $80 \times$ Sudan III 束状層表層脂肪稍々增加寸る。

（4）去勢後 $「 I 」$ 投与第 2 群 $80 \times$ H.E 皮質静脈洞の桩張と束状層の細胞の肥大增生が 著明である。

（5）去勢後 $「 I 」$ 投与第 3 啋 $80 \times \mathrm{PAS}$ （4）之同様束状層の細胞の肥大增生が著しい。

（6）去勢後「I」投与第 4 群 $80 \times$ Sudan III

（2）（3）飞比し束状層の肥大が著明で, 求状層 飞脂肪恃認められず, 束状層表層の細胞は脂肪 で全く充たされて居る.

（7）去勢後 $「 I 」$ 投与第 5 群 $80 \times$ H.E 束状層水小壊死巣が散在して認められる。

図 5 甲状腺

(1) 正常対称群 H.E $80 x$

（2）去勢後 4 週 H.E $80 x$ 大滤胞が多くなる。

（3）去勢後 20 週 H.E $80 x$ かなり大きい大濾胞が発現し，全く大滤胞性で ある。

（4）去勢後「I」投与第 1 群 H.E $80 x$ 大滤胞は減少して，小滤胞が多くなる。

（5）去樊後 $「 I 」$ 投与第 2 群 H.E $80 \times$ 未だ大濾胞が残つて居る

（6）去勢後 $「 I 」$ 投与第 3 櫂 H.E $80 x$ コロイド淡く，上皮丈高く骰子状上皮から成る 小濾胞の增生が全く著明である。

（7）去勢後「I」投与第 4 群 H.E $80 x$ 秒々大きな滤胞の出現を見る。

（8）去勢後「I」投与第 5 群 H.E $80 x$
コロイド濃く，上皮扁平な大滤胞からなる。

図 6 肝臓

（1）去勢後 $\Gamma I 」$ 投与第 5 群 H.E $100 x$

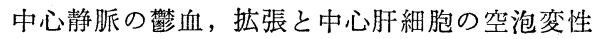
を見る。

（2）去勢後「I」投与第 5 群 H.E $100 x$ 肝細泡状となり，麻々核濃縮，崩壊消失を見る

（3）去勢後 $「 I 」$ 投与第 3 群 カルノア固定 PAS 染色 $100 x$

肝細胞グリコーゲンは正常と差異を認める程の 変化はない。

（4）去勢後「I」投与第 5 群 Sudan III $100 x$ 小葉間胆管より小胆管の軽度分岐增生と，その 上皮に於ける脂肪の沈着。

（5）去勢後「I」投与第 5 群 鉄染色 $100 \times$ 小葉周辺部肝細胞に血鉄素の沈着が著明に見ら れる。

図 7 脾臟

（1）去勢後「I」投与第 5 群 $40 \times$ H.E 淋巴濾胞の萎縮が見られる。

（2）去勢後「I」投与第 5 群 $40 \times$ 鉄染色 担鉄細胞が著しく多い,

（3）去勢後「I」投与第 3 群 $400 \times$ PAS 染色 PAS 陽性の原形質を有する所謂 Kurlof cell

図 8 腎臓

（1）去势後 6 週 Azan mallory $400 x$ 細尿管主部上皮細胞の溷濁腫脹

（2）去勢後 $「 I 」$ 投与第 4 群 H.E $100 x$ 細尿管主部上皮の变性が見られる。

（3）去勢後 $\Gamma I 」$ 投与第 5 群 Azan mallory $400 x$ 細尿管主部に 於ける管腔の 拢張と上皮の扁平 化, 可染顆粒が多数認められ，著しい変性像を 示す.

\section{Summary}

After a certain period following castration groups of mature female rabbits were injected aubcutaneously at their back with $15 \mathrm{mg}$ of estrogen pellet 1, 2, 3, 4 and 9 times at intervals of every 2 weeks, killed 2 weeks after the final administration and divided into 5 groups of 2 to 4 rabbits each according to total doses of 15 to $135 \mathrm{mg}$ and periods of 2 to 18 weeks administered to produce the experimental hyperestrongenism with progesteron effect intercepted.

Meanwhile, in order to confirm effccts of castration at each period, pathological, anatomical and histological examination were conducted chiefly on their uterus, mammary gland, pituitary body, thyroid gland, suprarenal gland, kidrey and liver together with those of 5 control groups of 2 castrated an:mals 
each. Experimental results were classified roughly into two categories according to dose of estrogen and period administered.

(1) In groups administered with 15 to $45 \mathrm{mg}$ of estrogen pellet for 2 to 6 weeks 2 weeks after castration the endometrium atrophined and thinned by castration indicated a remarkable glandular proliferation, and the muscularis mucosae thinned was also hyperthophied several times. Until 6 weeks after castration the mammary gland not different from non-functional and normal control proliferated like fibroadenia and acinar adenosis, and the abmornally proliferated focus of galactophorous glands was noted. Up to 6 weeks after castration appearance of acidophile celles instead of basophile cells became remarkable in the anterior hypophysis where the latter was to proliferate, chromophobic cells also developed and eflect of castration was inhibited by administration of estrogen. The cortex became slightly hypertropeied 2 to 4 weeks after castration. Four weeks later fat decreased in the fascicular Layer of suprarenal cortex, but a large amount of fat was still encountered in the coniform layer of suprarenal cortex. However, continual decrease of fat was found in the fascicular Layer, and cells were hypertrophied from the depth to the reticular layer. The thyroid gland was reduced in function, was concentrated in colloid, and indicated large follicles due to castration. But it was weakened in the colloid, indicated small follicles and was enhanced in function due to administration of estrogen. Extending over prolonged period after castration binuclear cells developed in atrophied liver, while central vein and venous sinus were congested and enlarged. Estrogen had no effect on the spleen where there was noted no remarkable cnange after castration. Degenerated epithelium of the principal part of the nephritic duct, which became distinct 2 to 4 weeks after castration, was recoverd by administration of estrogen.

(2) In groups administered with 60 to $135 \mathrm{mg}$ of estrogen pellet for 8 to 18 weeks after castration the endometrium was markedly infiltrated with leukocytes showing the necroosis or the necrobiosis. The infiltra tion extended into the muscularis mucosae, and vein and cepillara of the uterine vagina were markedly congested and enlarged, part of them indicating the thrombosis. However, the residual muscularis mucosae was rather proliferative, and in groups administered with $135 \mathrm{mg}$ of the medicine for 8 weeks the fibroma was formed below the serous membrane. In the mammary glands where rami of the galactophorous ducts temporarily exteded and the epithelium proliferated, lobules collapsed completely and large cystic mastopathy seemed to appear. In the anterior hypophysis surrounded by the stroma acidophile cells decreased and collapsed, while basophile cells diminished markedly and chromophobic cells increased remarkably instead. Fat in the coniform layer of the suprarenal cortex disappeared entirely, but a considerable amount of fat was noted in the fascicular layer. Concentration, collapse and disappearance of cytoblasts were noted. In groups administered with $135 \mathrm{mg}$ of estrogen pellet for 8 weeks the coniform layer also degenerated and small necrotic foci were scattered in the fascicular layer revealing remarkably devastared area. The thyroid gland, which had once indicated small follicles, again rerealed large follicles on account of dense colloid being accumulated. In groups administered with large dose of the medicin for long periop the remarkable cellular degeneration was encountered in the central part of the liver lobule, and slight growth of small bile ducts took place in Glisson's capsule. Spleen sevealed markedly atrophied lymphatic follicles at the later period. Epithelium of the principal part of the nephritic duct once seemingly recovered dy administration of estrogen, degenerating remarkably, became flat.

The duct sprce was enlarged, became vitreous and degenerated. Nuclei were densely stained, and radiated ints the duct. Picture of the extensive and strong degeneration was noted.

Department of Pathology, Juntendo University, School of Medicine. 
阿部論交附図（I）

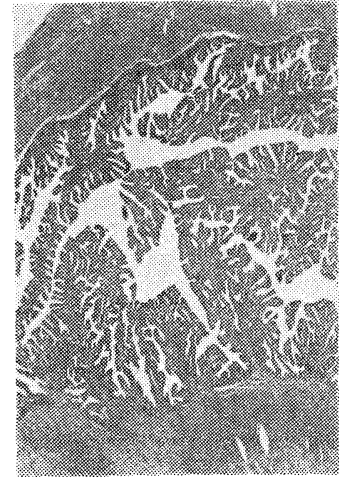

図 1-1

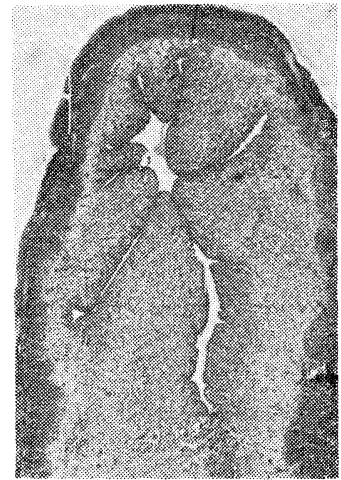

図 1-2

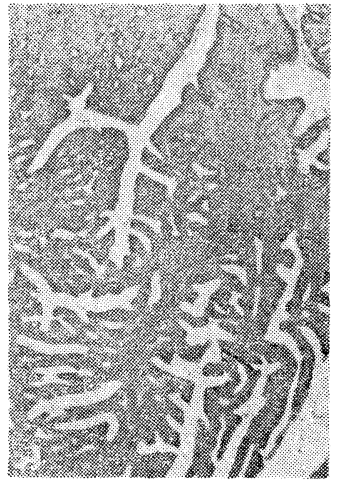

図 1-3

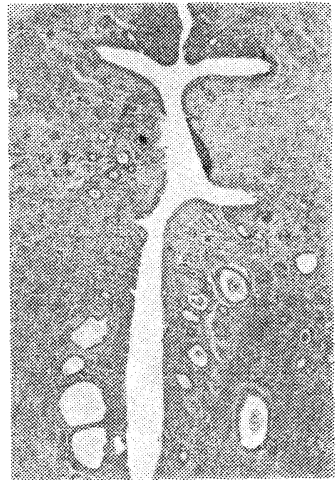

図 1-4

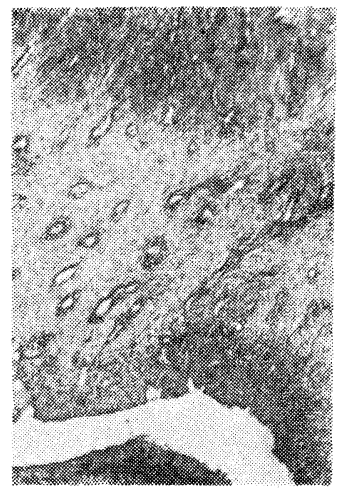

図 1-5

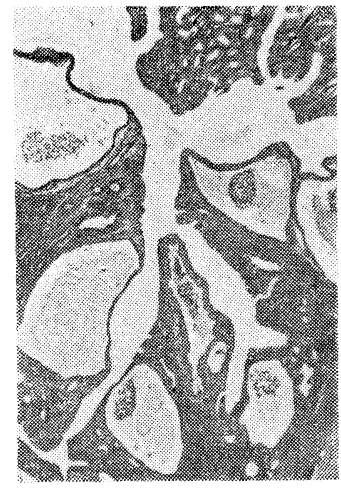

図 1-6

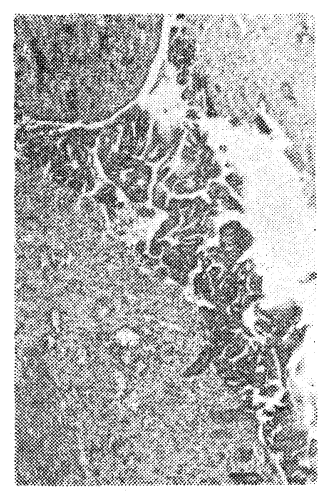

図 1-7

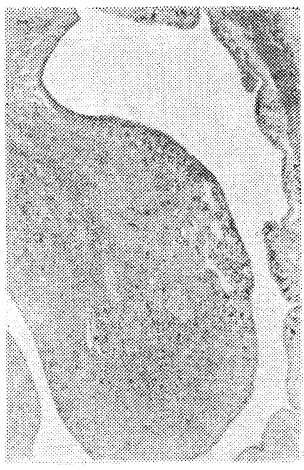

図 1-8

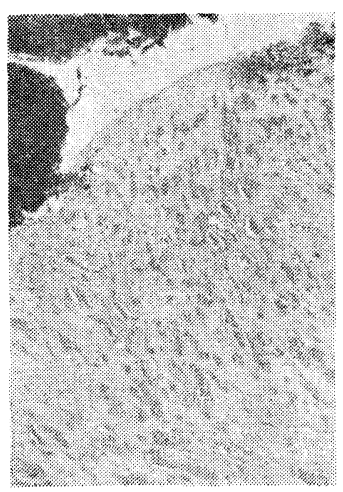

图 1-9

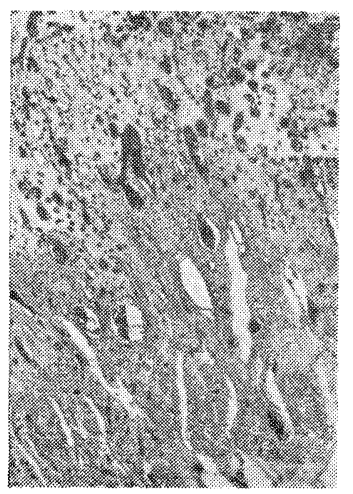

图 1-10

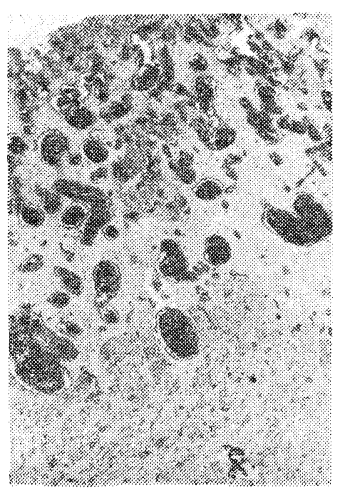

図 1-11

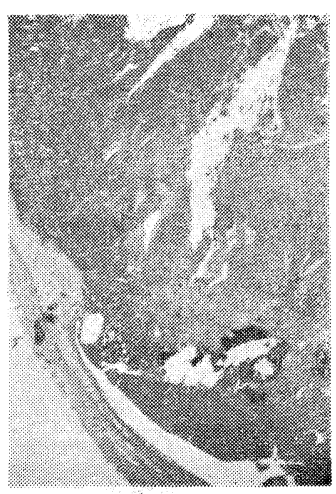

図 1-12 
阿部論交附図（II）

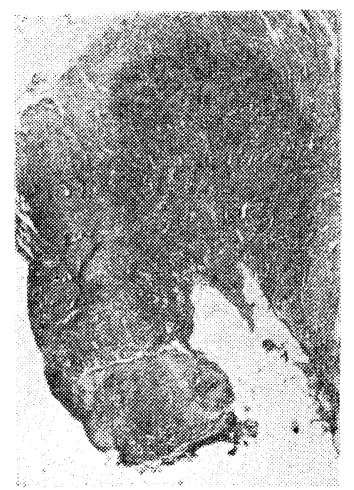

図 1-13

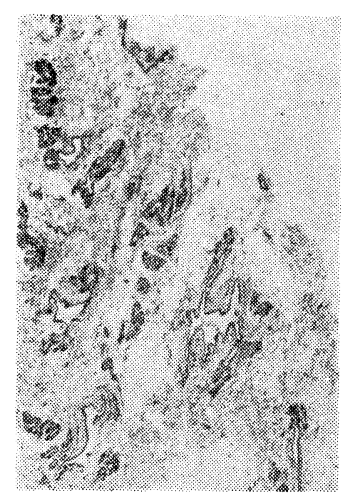

図 2-1

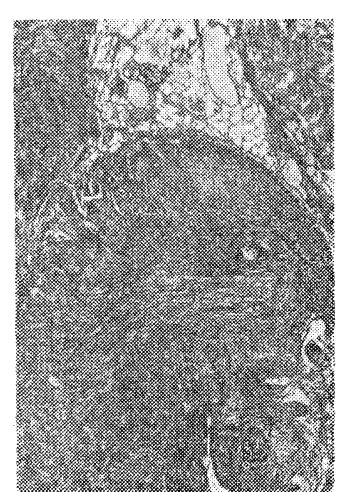

図 1-14

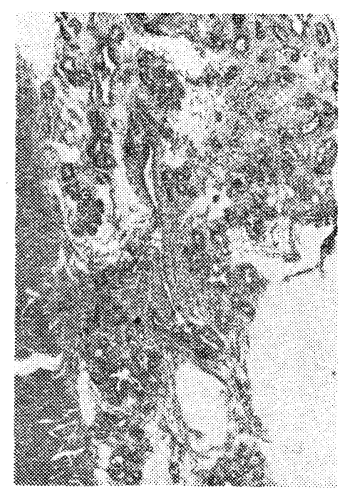

図 2-2

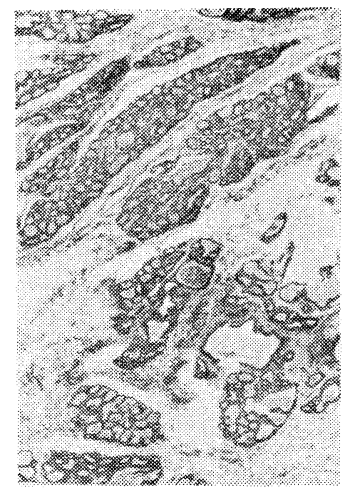

図 2-3

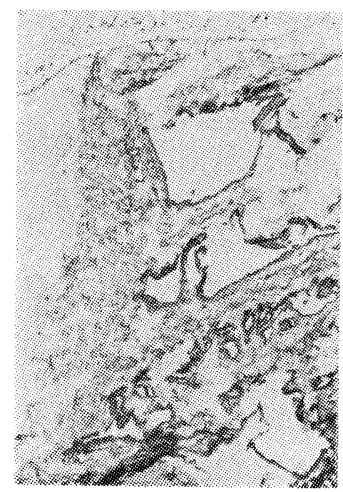

图 2-4

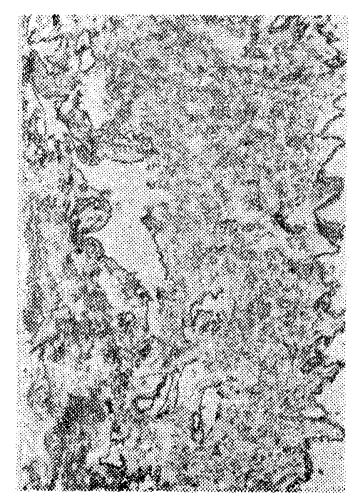

図 2--5

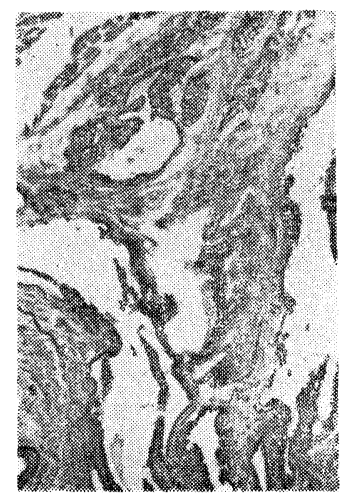

图 26



图 2-7 


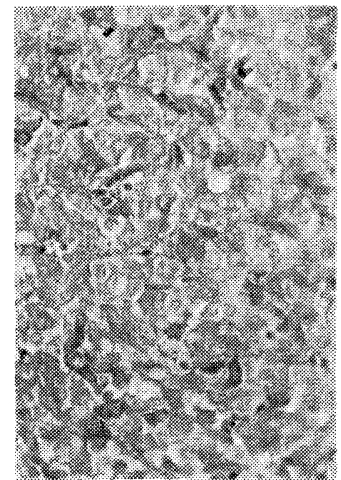

图 3-1

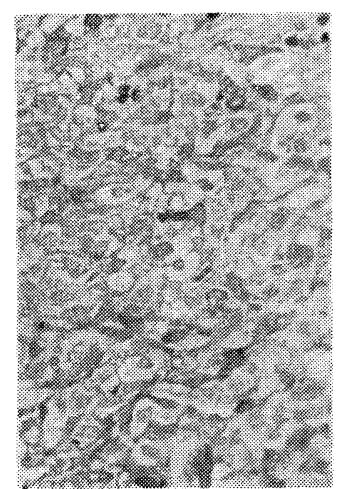

图 3-2

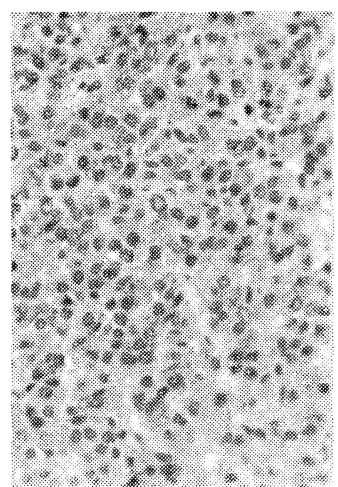

図 3-3

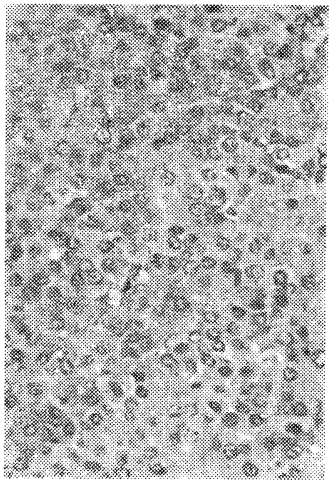

图 3-4

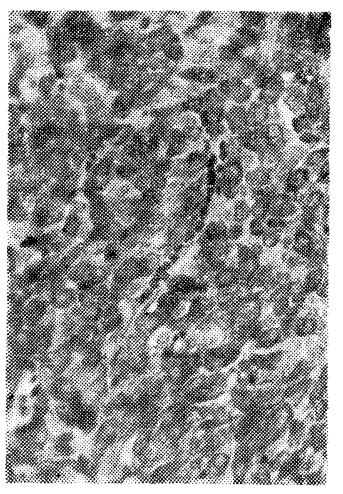

図 3-5

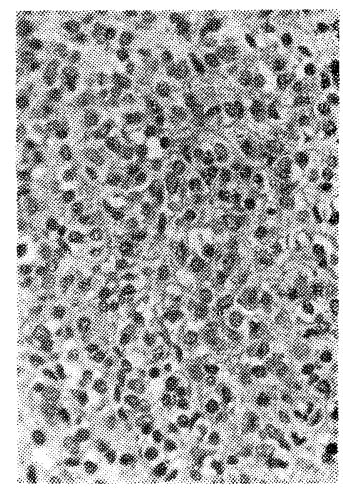

図 3-6

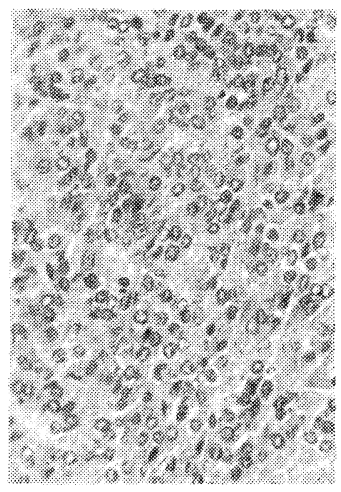

図 3-7

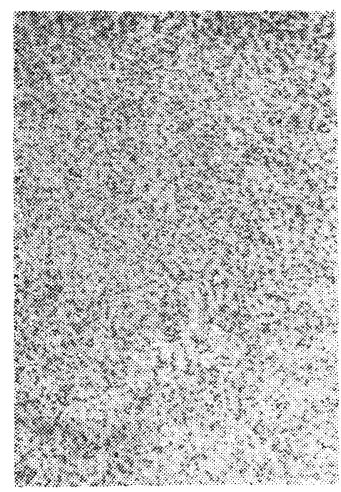

図 4-1

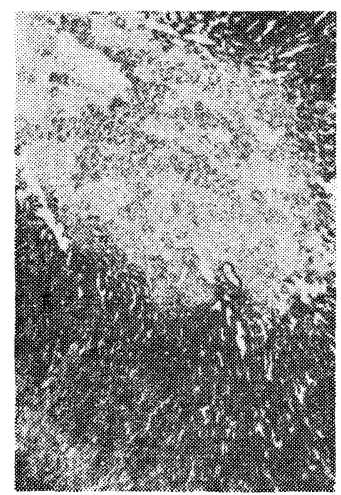

図 4-2

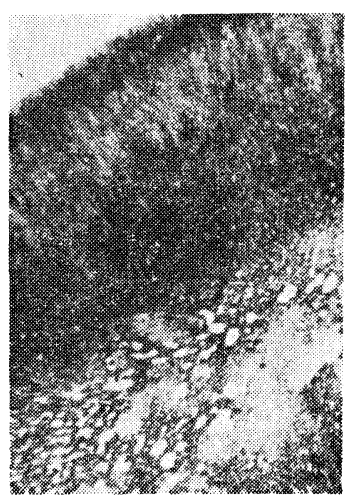

図 4-3

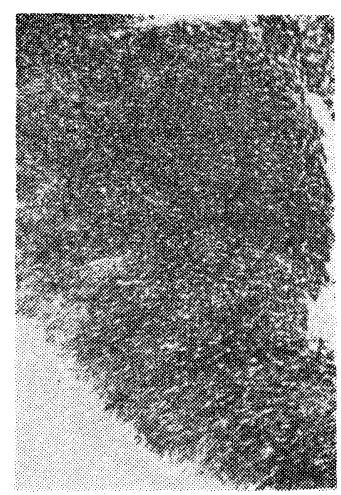

图 4-4 
阿部論交附図 (IV)



図 4-5



図 4-6



図 4-7

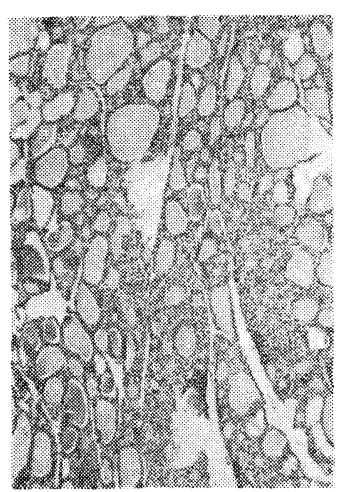

図 5-1

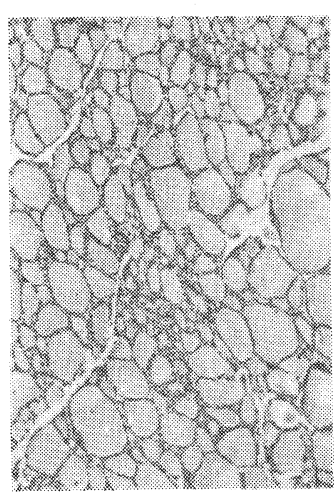

図 5-2

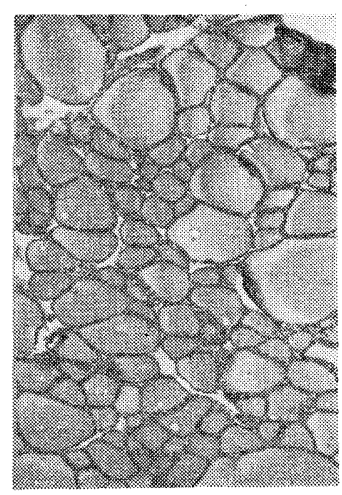

図 5-3



図 5-4

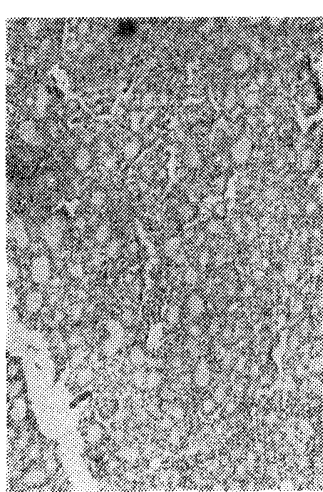

図 $5-6$



甽 5-7



図 $5-8$ 
阿部論 交附図 (V)

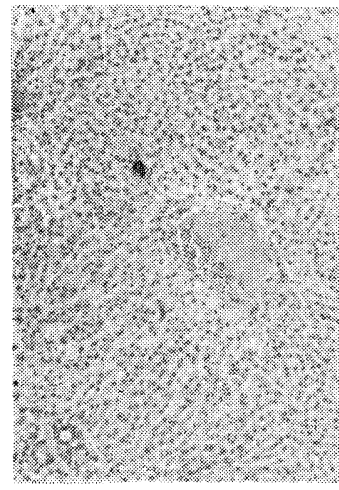

図 6-1

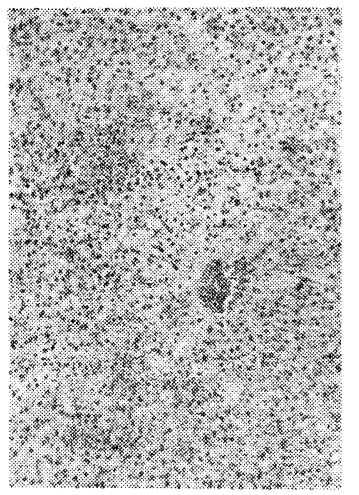

图 6-2

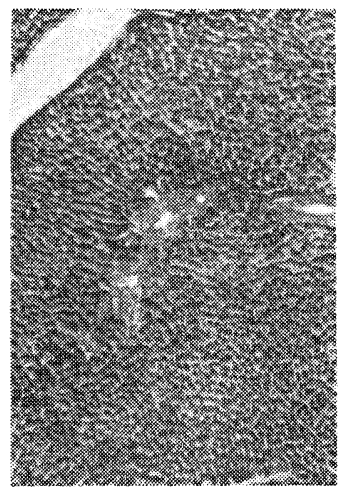

図 6-3

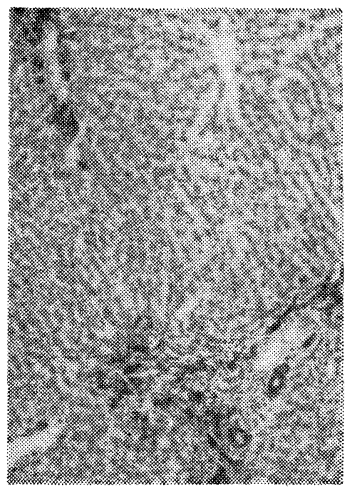

図 6-4

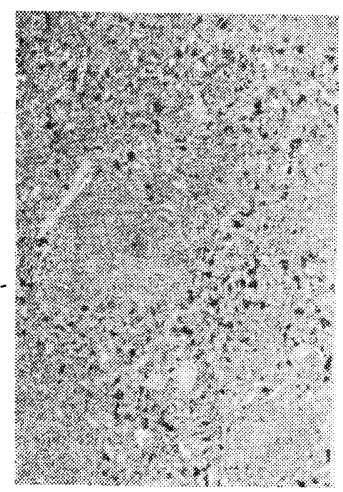

図 7-1

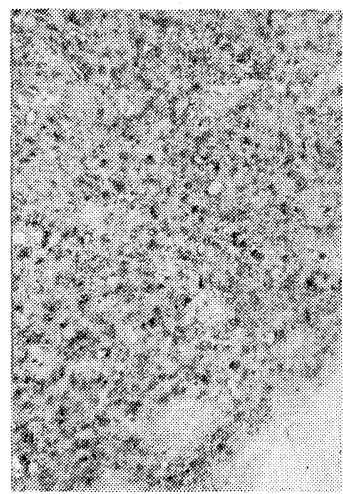

図 7-2

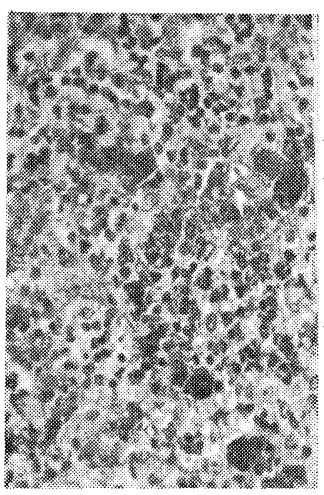

図 7-3

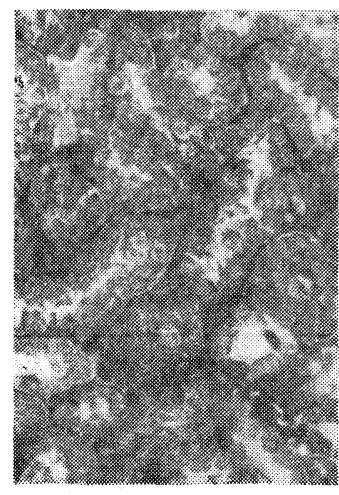

图 8-1

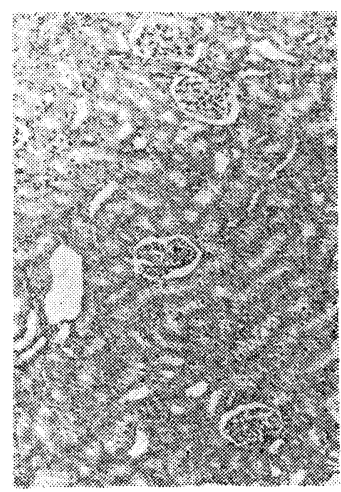

图 8-2



图 8-3 